\title{
The ultrastructure of spermatozoa and spermiogenesis in pyramidellid gastropods, and its systematic importance
}

\author{
John M. Healy \\ School of Biological Sciences (Zoology, A08), University of Sydney; 2006, New South \\ Wales, Australia
}

\begin{abstract}
Ultrastructural observations on spermiogenesis and spermatozoa of selected pyramidellid gastropods (species of Turbonilla, Pyrgulina, Cingulina and Hinemoa) are presented. During spermatid development, the condensing nucleus becomes initially anterio-posteriorly compressed or sometimes cup-shaped. Concurrently, the acrosomal complex attaches to an electrondense layer at the presumptive anterior pole of the nucleus, while at the opposite (posterior) pole of the nucleus a shallow invagination is formed to accommodate the centriolar derivative. Midpiece formation begins soon after these events have taken place, and involves the following processes: (1) the wrapping of individual mitochondria around the axoneme/coarse fibre complex (2) later internal $^{2}$ metamorphosis resulting in replacement of cristae by paracrystalline layers which envelope the matrix material; and (3) formation of a glycogen-filled helix within the mitochondrial derivative (via a secondary wrapping of mitochondria). Advanced stages of nuclear condensation (elongation, transformation of fibres into lamellae, subsequent compaction) and midpiece formation proceed within a microtubular sheath ('manchette'). Pyramidellid spermatozoa consist of an acrosomal complex (round to ovoid apical vesicle; column-shaped acrosomal pedestal), helically-keeled nucleus (short, 7-10 $\mu \mathrm{m}$ long, shallow basal invagination for axoneme/coarse fibre attachment), elongate helical midpiece (composed of axoneme, coarse fibres, paracrystalline and matrix materials, glycogen-filled helix), glycogen piece (length variable, preceeded by a dense ring structure at junction with midpiece). The features of developing and mature spermatozoa observed in the Pyramidellidae are as observed in opisthobranch and pulmonate gastropods indicating that the Pyramidelloidea should be placed within the Euthyneura/Heterobranchia, most appropriately as a member group of the Opisthobranchia.
\end{abstract}

\section{INTRODUCTION}

The Pyramidellidae (superfamily Pyramidelloidea) is a large and widespread group of shelled, operculate gastropods living typically in an ectoparasitic association with epifaunal bivalves and tube-dwelling polychaetes (Fretter \& Graham, 1949, 1962; Robertson, 1978; Ponder, 1973). The systematic position of the Pyramidellidae within the Gastropoda has long been a subject for debate among malacologists and palaeontologists. The presence of a well-developed, usually tall-spired shell and a chitinous oper-

Address for correspondence: Department of Zoology, University of Queensland, St. Lucia 4067. Brisbane, Queensland, Australia 
culum have often been cited as evidence of their prosobranch affinity. However, studies of pyramidellid anatomy, in particular the structure of the reproductive system and sensory organs, as well the presence of a heterostrophically-coiled shell, indicate that these gastropods are most appropriately referred to the subclass Opisthobranchia (Fretter \& Graham, 1949; Knight et al., 1960; Ghiselin, 1966). This position for the Pyramidellidae, now generally accepted in modern classifications, is corroborated by light microscopy on spermiogenesis (various pyramidellids, Franzén, 1955), electron micrographs of the late spermatid midpiece and nucleus of Odostomia sp. presented by Thompson (1973), and also by osphradial fine structure (Haszprunar, 1985a). Recent attempts by some authors to return the Pyramidellidae to the Prosobranchia (e.g. see Golikov \& Starobogatov, 1975; Gosliner, 1981; Boss, 1982 $i$ Robertson, 1985) suggest perhaps that the full significance of available data on pyramidellid spermatozoa/spermiogenesis has not been fully appreciated. The purpose of this study is to provide detailed ultrastructural information on spermiogenesis and spermatozoa of pyramidellid gastropods in order to confirm the opisthobranch position usually accorded this group.

\section{MATERIALS AND METHODS}

Pyramidellid species used in this study were obtained from the following localities: Tangalooma Channel, Moreton Bay, southern Queensland (Cingulina sp.); Redcliffe, Moreton Bay (Pyrgulina sp.); Lota, Moreton Bay (Turbonilla sp.); Fairlight, Sydney Harbour, New South Wales (Hinemoa sp.). Gonad tissues were fixed in cold $2.5 \%$ glutaraldehyde (prepared in $0.2 \mathrm{M}$ sucrose-adjusted phosphate buffer) for two hours, rinsed in buffer ( $30 \mathrm{mins}$ ), post-fixed in $1 \%$ osmium tetroxide prepared in phosphate buffer $(80 \mathrm{mins})$, rinsed in buffer, dehydrated with ethanol and finally embedded in

Fig. 1. Cingulina sp. A Early stage of acrosome formation - Golgi complex adjacent to acrosomal vesicle $(\times 50400)$. B Early spermatid nucleus - anterior plaque has formed close to developing acrosome $(\times 17600)$. C Transverse section through acrosome during attachment phase - the support structure (cylindrical) is attached to acrosomal pedestal via forked links $(\times 48700)$. D Slightly oblique longitudinal section through acrosome attaching to nuclear apex $(\times 44800)$. E Early spermatid with acrosome and axonemal complex attached to opposite poles of nucleus $(\times 16800)$. F Acrosome attached to nuclear apex of early spermatid (same stage as Fig. $1 \mathrm{E}$ ) showing acrosomal pedestal, apical vesicle and support structure $(\times 40300)$. G Basal invagination of early spermatid nucleus (early fibrillar phase of condensation) - note centriolar derivative and proximal portion of axoneme/coarse fibre complex $(\times 47900)$. H Longitudinal section through acrosome and nuclear apex of advanced spermatid $(\times 37000)$

Abbreviations:

a acrosome

ap acrosomal pedestal

av apical vesicle (acrosomal vesicle)

ax axoneme

cd. centriolar derivative

cf coarse fibres

drs dense ring structure (annulus)

G Golgi complex

gh glycogen helix

gp glycogen piece

m mitochondria

ma matrix component of mitochondrial derivative

$\mathrm{mt}$ microtubules

n nucleus

nk nuclear keels

$\mathrm{p}$ paracrystalline component of mitochondrial derivative

ss support structure of acrosomal complex 

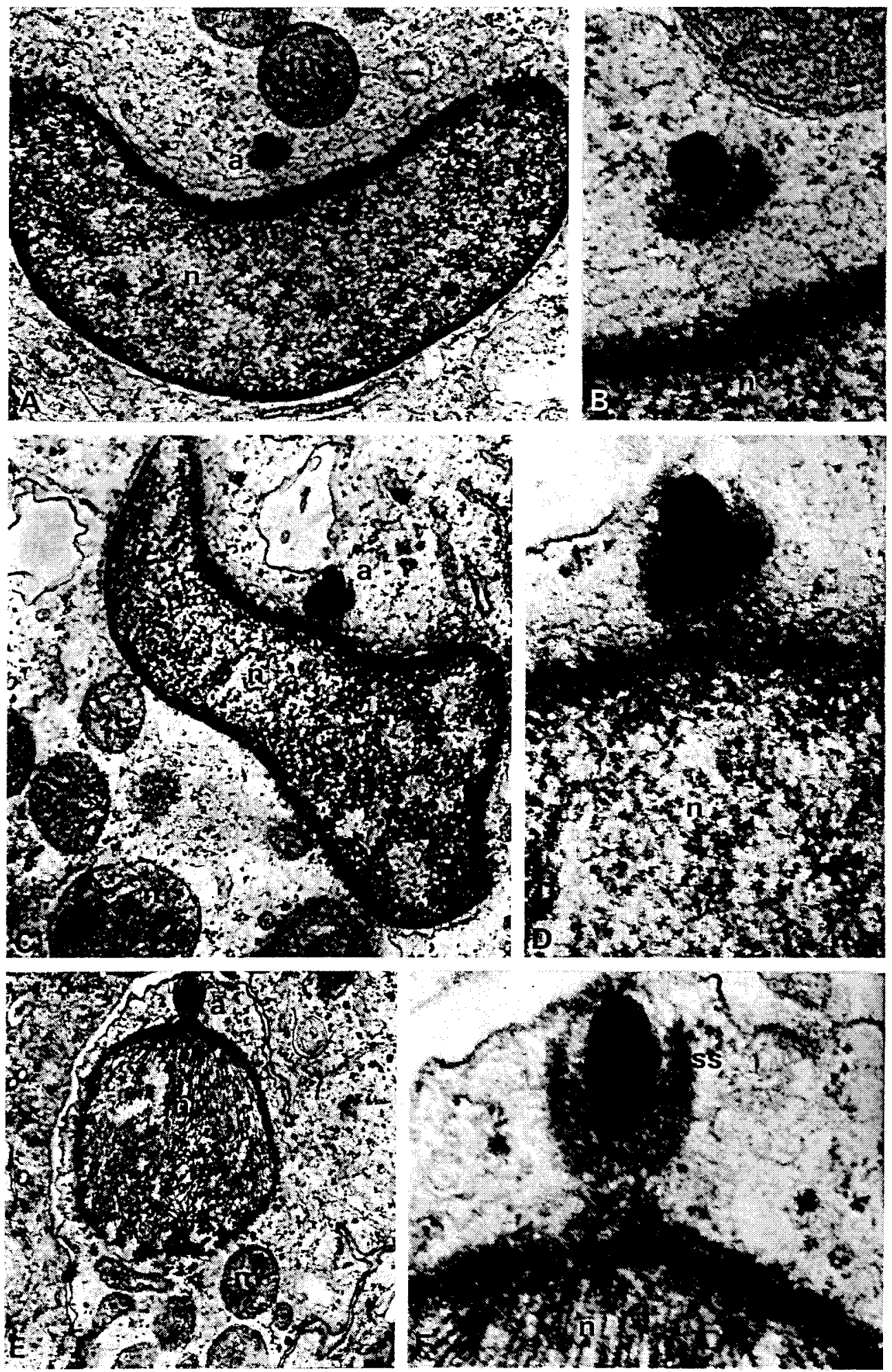
$5 \mathrm{~A}, \mathrm{~B}, \mathrm{D})$. A single sheath of microtubules surround the nuclear periphery during the lamellar phase of condensation (Figs $1 \mathrm{H}, 3 \mathrm{D}, \mathrm{E}$ ) and persist very late in development (Figs 5A-D). Possibly this sheath assists in the formation of the helical keels present in late spermatids and mature sperm (helical keels visible in Fig. 5D).

\section{Midpiece development}

Formation of the midpiece occurs after mitochondria have collected at the posterior pole of the condensing nucleus (polarity established after acrosome attachment and anchorage of the centriolar derivative/axonemal complex have been effected). Prior to this, mitochondria are scattered throughout the spermatid cytoplasm (Figs 1B, 2A). Initially, mitochondria cluster around the proximal region of the axoneme/coarse fibre complex (Figs 1E, G), where they begin to fuse into a single sheath (the primary wrapping phase: Figs $3 \mathrm{C}, 4 \mathrm{~A}-\mathrm{C}$ ). The presence of a well developed Golgi complex during midpiece formation (Figs $4 \mathrm{~A}, \mathrm{~B}$ ) suggests that it may itself be involved in this aspect of spermiogenesis - perhaps facilitating fusion of mitochondria. The process of mitochondrial fusion spreads posteriorly and, after the primary wrapping is complete, a secondary wrapping phase begins (Fig. 4D) during which cristae are replaced by helically-orientated paracrystalline fibres (organized in layers) and the glycogen helix is formed. In late spermatids and mature spermatozoa (Figs $5 \mathrm{E}, 6 \mathrm{C}-\mathrm{H}, J$ ), the paracrystalline layers enclose the now subdivided matrix material and a helically-coiled compartment filled with glycogen deposits/granules (Figs 6D, E, F, J). A microtubular sheath, probably continuous with that associated with the condensing nucleus, surrounds the midpiece after completion of the secondary wrapping phase (Figs $4 \mathrm{E}, \mathrm{F}$ ). This sheath of microtubules is absent in mature spermatozoa (see Figs $6 \mathrm{C}-\mathrm{G}, \mathrm{J}$ ), but presumably has some function in molding the helical features of the midpiece. Development of the glycogen piece was not traced.

\section{Mature spermatozoa}

Fully mature acrosomes were not observed. However in very late spermatids the acrosomes are clearly composed of an apical vesicle (ovoid to spherical) surmounting a short columnar pedestal (Hinemoa Fig. 6A; Turbonilla Fig. 6B; see Fig. $1 \mathrm{H}$ for spermatid acrosome of Cingulina). The support cylinder and microtubules surrounding these late spermatid acrosomes presumably are lost in fully mature spermatozoa, as is the case in other euthyneuran spermatozoa (Healy, 1984). The nuclei of all pyramidellid species examined are relatively short $(7-10 \mu \mathrm{m})$, shallowly invaginated at the base (Fig. 5A) and usually show one to three helically-shaped keels (Figs 5B-D). In another pyramidelloidean Ebala nitidissima Montagu, the nucleus is long and almost totally penetrated by the

Fig. 3. Turbonilla sp. A Early spermatid with attached acrosome $(\times 16800)$. B Detail of Fig. 3A $(\times 52500)$. C Spermatid at slightly later stage than Fig. $3 \mathrm{~A}-$ the axoneme/coarse fibre complex is well developed but the central pair of axonemal microtubules do not contact the centriolar derivative. Note wrapping of metamorphosing mitochondria around the axoneme and developing coarse fibres $(\times 27700)$. D Later spermatid than Fig. $3 \mathrm{C}$ - nucleus has elongated and plasma membrane has become tightly wrapped over acrosome and nucleus ( $\times 15500)$. E Transverse section through nucleus at stage shown in Fig. 3D - fibrillar substructure altered to lamellar ( $\times 30200)$ 

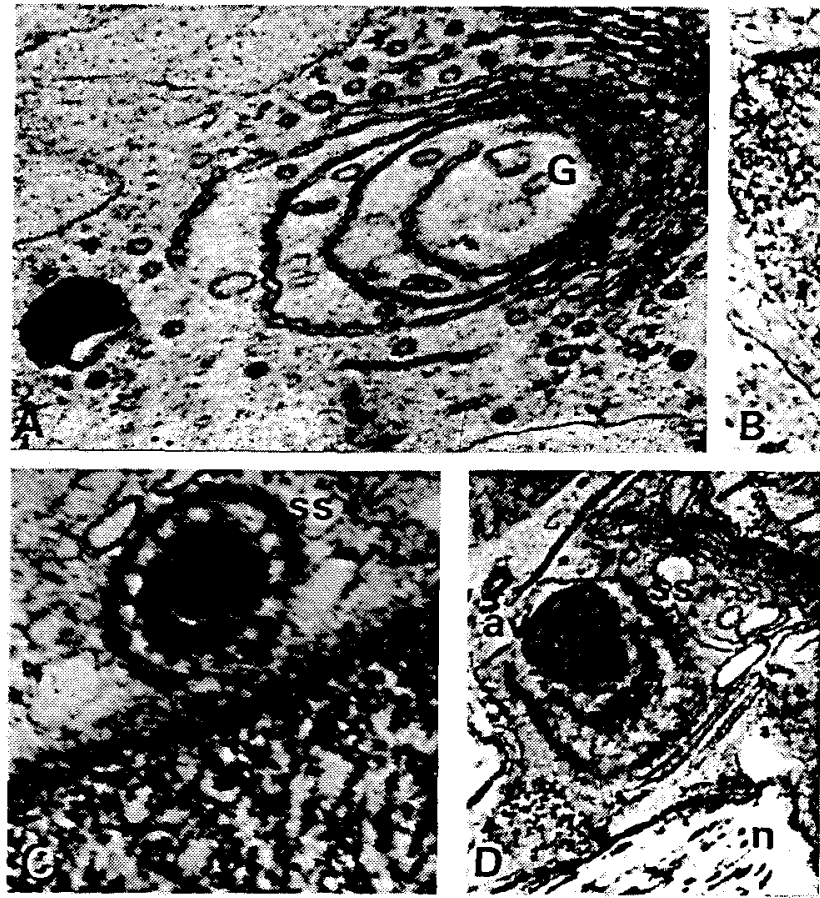

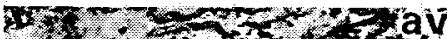
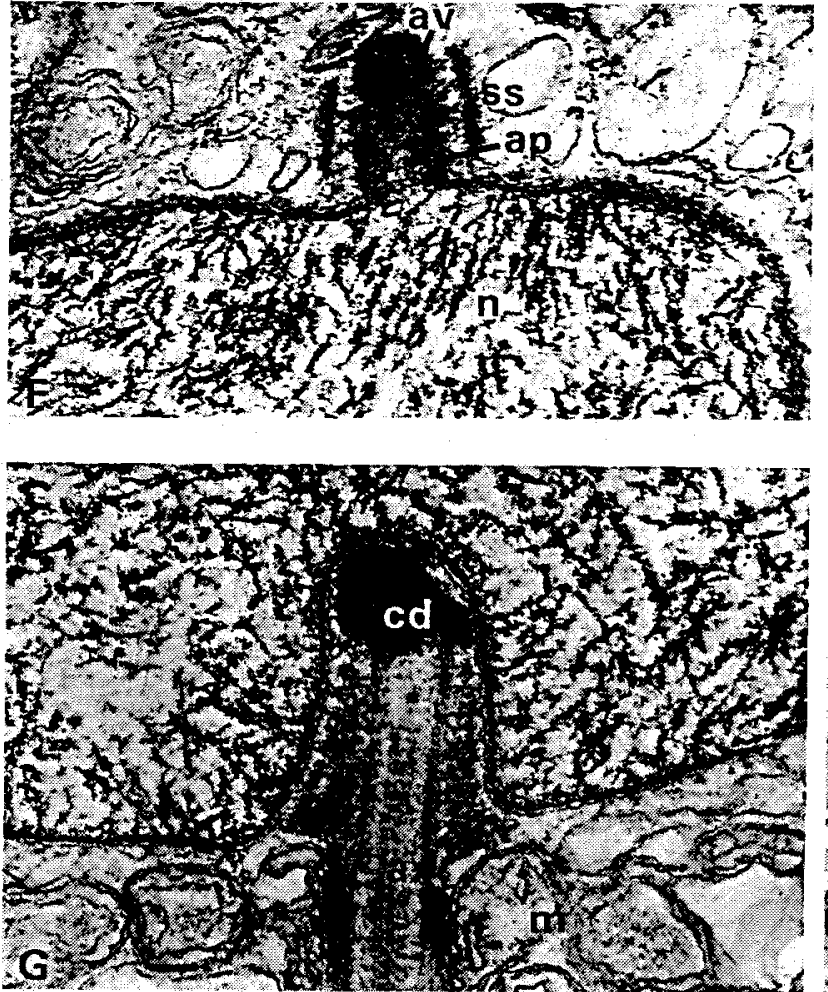
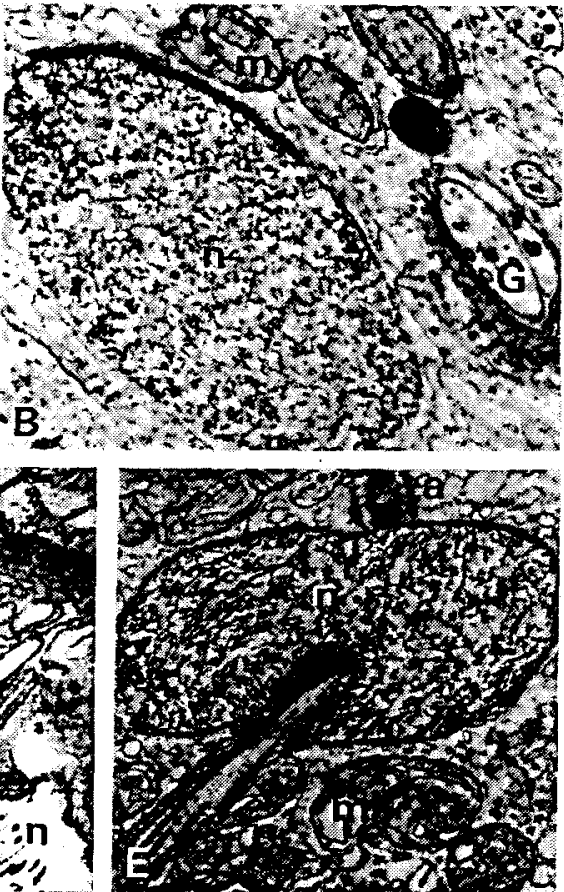

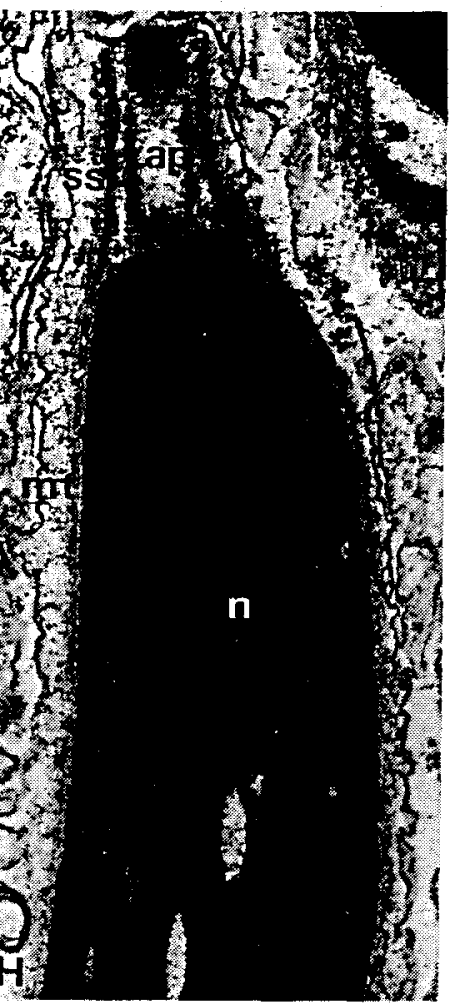


Spurr's epoxy resin. Ultrathin sections for transmission EM were cut using an LKB IV Ultrotome, collected on uncoated copper grids, stained with $4 \%$ aqueous uranyl acetate and Reynold's lead citrate, and examined with AEI Corinth 500 or Philips 300 transmission electron microscopes operated at $60 \mathrm{kV}$. Voucher specimens of the species used in this study have been lodged with the Australian Museum (Sydney) (Cingulina sp. C. 142559; Turbonilla sp. C. 142558; Pyrgulina sp. C. 142564; Hinemoa sp. C. 154737).

\section{RESULTS}

\section{Spermiogenesis}

Acrosome, nucleus

Spermiogenesis was traced in Cingulina sp. (Fig. 1) and Turbonilla sp. (Figs 2-5) from the beginning of acrosome development to the final stages of nuclear condensation (and shaping) and midpiece formation. The acrosomal complex commences as a subspherical, dense, membrane-bound vesicle (diameter $0.2 \mu \mathrm{m}$, Cingulina) derived, it appears, from a well-developed Golgi complex (Figs 1A,B). Whether this vesicle is formed from a modified Golgi cisterna or from the fusion of vesicles budded from cisternal edges is not clear. Figure $1 \mathrm{~B}$ shows that the early spermatid nucleus of Cingulina, though relatively uncondensed, already has a distinct plaque lining its outer membrane (the future anterior pole of the spermatid nucleus). Golgi complexes and the developing acrosome are in close proximity. As nuclear contents are converted from a granular to fibroreticular fabric, attachment of the acrosome to the dense extra-nuclear plaque takes place (Figs 1C,D Cingulina; Figs 2A-F Turbonilla). During this phase of development, the acrosomal complex becomes structurally more elaborate, having acquired subvesicular material from an undetermined source (not evidently from the Golgi complex; possibly an endoplasmic reticular product) as well as an enveloping 'support' cylinder (Figs $1 \mathrm{C}-\mathrm{F}_{2}, 2 \mathrm{~A}-\mathrm{F}$ ). In Cingulina, the cylinder is attached to the acrosomal complex via a series of 15 or 16 terminally-pronged fibres (see Fig. $1 \mathrm{C}$ ). The condensing nucleus is now noticeably compressed anterio-posteriorly (Figs $1 \mathrm{E}, 2 \mathrm{C}$ ), and in Turbonilla may be initially cup-shaped (Figs $2 \mathrm{~A}, \mathrm{C}$ ). Lodged within the basal invagination of the spermatid nucleus is an electron-dense body, - the centriolar derivative (Figs 1G, 3C) attached to which are the $9+2$ axoneme and developing coarse fibres. Following acrosomal attachment (and contact of acrosome with the plasma membrane), nuclear elongation and midpiece formation commences (Figs $1 \mathrm{H}, 2 \mathrm{E}, \mathrm{F}, 3 \mathrm{~A}-\mathrm{E}, 4 \mathrm{~A}-\mathrm{F}, 5 \mathrm{~A}, \mathrm{~B}, \mathrm{D}$ ). The condensing nucleus becomes pyriform with constituent fibres oriented longitudinally (Fig. $3 \mathrm{C}$ ). As elongation proceeds, fibres are transformed into closely-packed lamellae (see Figs $1 \mathrm{H}$, $3 \mathrm{D}, \mathrm{E})$. Spaces within the spermatid nucleus are visible even at a relatively late stage of condensation (Figs $1 \mathrm{H}, 3 \mathrm{E}$ ), but are gradually eliminated as maturity approaches (Figs

Fig. 2. Turbonilla sp. A Early spermatid acrosome approaching nuclear apex (nucleus at 'cup stage' of Eckelbarger \& Eyster, 1981) $(\times 21000)$. B Detail of acrosome shown in Fig. 2A $(\times 55900)$. C Acrosome approaching nuclear surface $(\times 21000)$. D Detail of Fig. $2 \mathrm{C}(\times 55900)$. E Acrosome attaching to nuclear apex - note rounded appearance of nucleus $(\times 14300)$. F Detail of Fig. $2 \mathrm{E}$ $(\times 58800)$ 

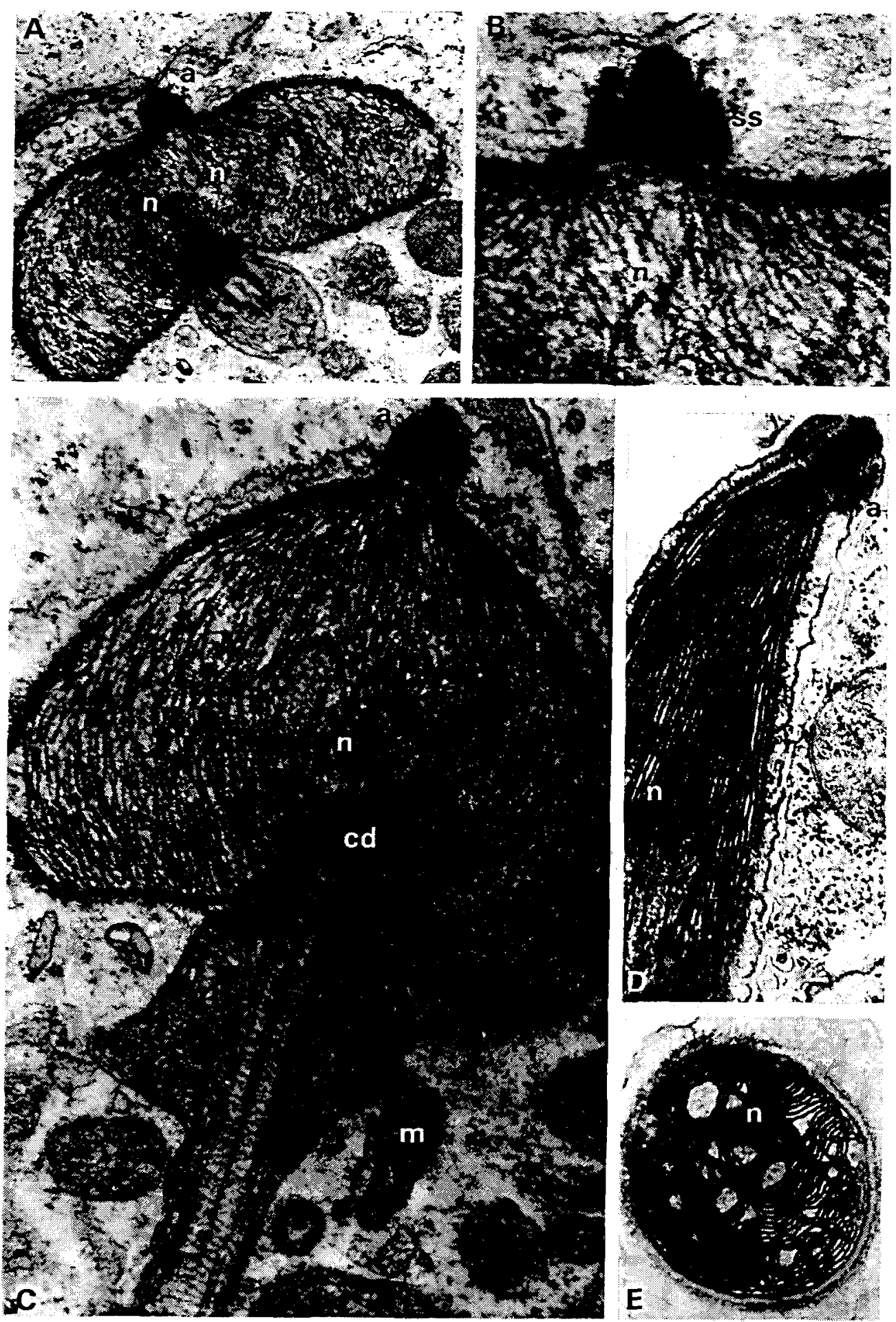
axoneme/coarse fibre complex (Healy, unpublished data). The centriolar derivative and proximal portion of the axoneme and coarse fibres occupy the basal invagination of the nucleus in Hinemoa, Turbonilla, Cingulina and Pyrgulina (see Figs 5A-D). The midpiece region in all cases consists of the axoneme (and accompanying coarse fibres) enclosed by the mitochondrial derivative (Figs 5D-F, 6C-H, J). Transverse and oblique longitudinal sections most clearly show the helical organization of the matrix and paracrystalline components of the mitochondrial derivative (Figs $6 \mathrm{C}-\mathrm{H}$ ). The matrix layers appear to be subdivided into distinct, helically-coiled tracts (Figs 6F, H, J). Only a single glycogen helix occurs within the midpiece in all pyramidelloidean spermatozoa (including those of Ebala) (Figs 5E, F, 6D-F, J). The glycogen helix is notably absent in the posterior region of the midpiece (Figs $6 \mathrm{G}, \mathrm{H}$ ). A glycogen piece occurs posterior to the midpiece in all species examined (Figs $5 \mathrm{G}, 6 \mathrm{C}, \mathrm{I}, \mathrm{K}$ ) and is preceeded by a dense ring at the midpieceglycogen piece junction (see Figs 5G, 6K). In Cingulina and Pyrgulina (Figs 6C, I, K) and Hinemoa, the axoneme progresses fully intact deep into the glycogen piece, while in Turbonilla the axoneme degenerates rapidly on entering the glycogen piece, leaving the lumen of this region filled by granular deposits (Fig. $5 \mathrm{G}$ ).

\section{DISCUSSION}

\section{Spermiogenesis}

The pattern of spermiogenesis described here for the Pyramidellidae does not deviate from that occurring in other euthyneuran species (Opisthobranchia: Eckelbarger \& Eyster, 1981; Kubo \& Ishikawa, 1981; Medina et al., 1985, 1986; see also Thompson, 1973 for micrographs of late spermatid midpiece in the pyramidellid Odostomia sp. Pulmonata: André, 1962; Takaichi \& Sawada, 1973; Takaichi \& Dan, 1977; Dan \& Takaichi, 1979; Terakado, 1981). Prior to the above mentioned electron microscopical studies, Franzén (1955) had established using phase-contrast light microscopy that spermiogenesis in euthyneurans, including pyramidellids, differed noticeably from the process as observed in other internally fertilizing gastropods, particularly with regard to formation of the sperm midpiece. At the ultrastructural level, distinctive features of euthyneuran spermiogenesis include: (1) attachment of a round acrosomal vesicle (associated with extra-vesicular material) to a plaque lining the anterior face of the spermatid nucleus; (2) production of periodically striated/banded coarse fibres associated with the axoneme (fibres rarely absent); (3) complete metamorphosis of mitochondrial material into paracrystalline and matrix materials (formation of the mitochondrial derivative); (4) incorporation of one or more helices of glycogen within the mitochondrial

Fig. 4. Turbonilla sp. A, B Wrapping and (arrows) fusion of mitochondria around the axoneme/coarse fibre complex at initial phase of midpiece formation. Note presence of well developed Golgi complex. $(A, \times 35000 ; B, \times 42300)$. C Complete enclosure of axoneme and coarse fibres by developing mitochondrial derivative (mid-spermatid, nucleus at fibrous phase of condensation) $(\times 38000)$. $D$ Beginning of second phase of mitochondrial wrapping (initial stage in the production of the glycogen helix) $(\times 45700)$. E Late spermatid midpiece. Note microtubular sheath, glycogen helix, coarse fibres and axoneme $(\times 55000)$. F Posterior portion of late spermatid midpiece (beyond termination of the glycogen helix) showing microtubular sheath $(\times 51200)$ 

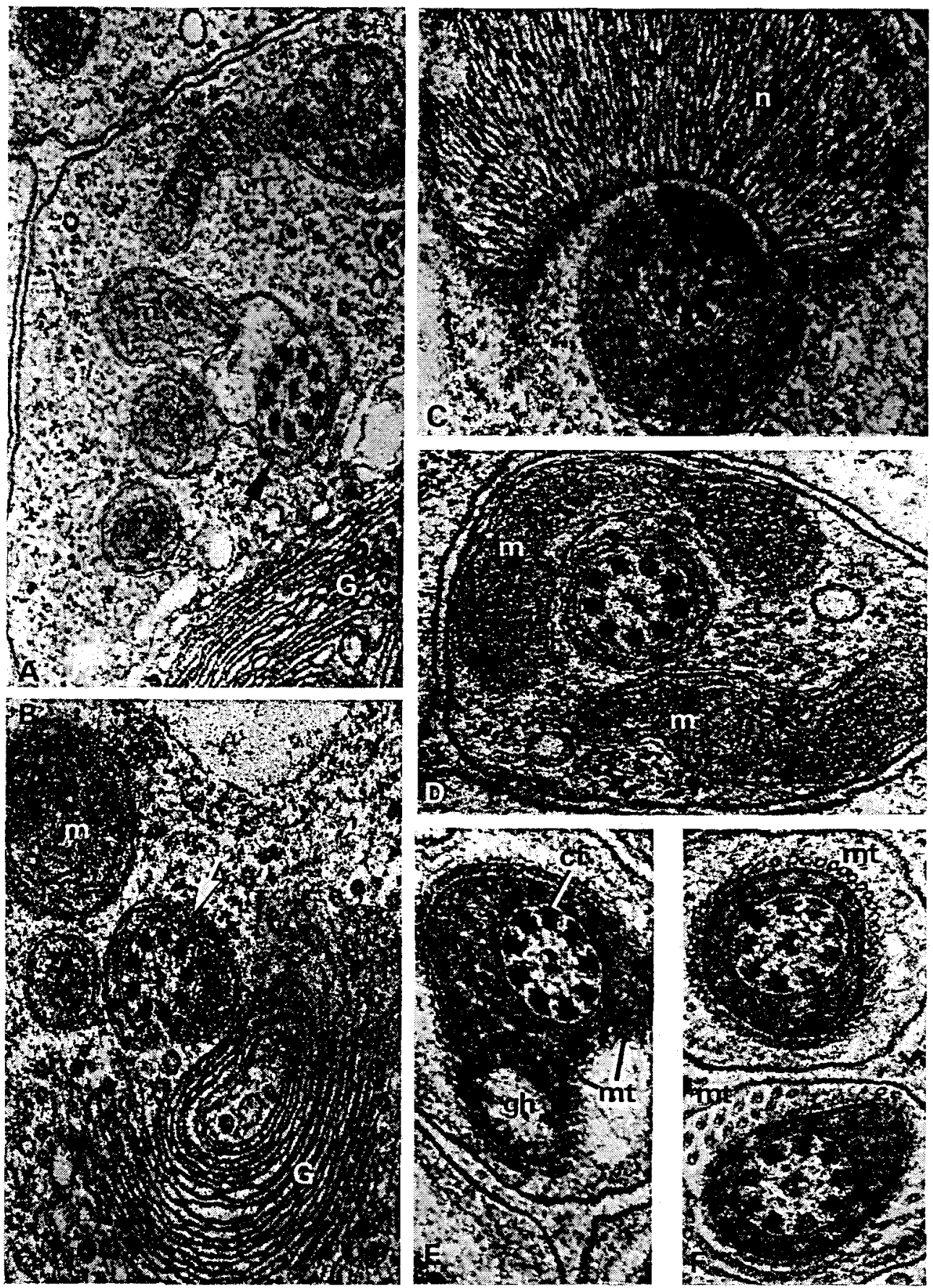
derivative (one helix in most euthyneurans, two to four in some basommatophoran pulmonates and cephalaspidean opisthobranchs: Thompson, 1973; Healy, 1983a, 1984). Other spermiogenic features such as the close association of the Golgi complex with acrosome development, the appearance of a microtubular sheath around the spermatid nucleus and midpiece, and the sequence of nuclear condensation phases (granular, reticular, fibrous, lamellar) are routinely reported in studies of spermiogenesis in mesoand neogastropod prosobranchs (for example, Buckland-Nicks \& Chia, 1976; Healy, $1982 \mathrm{a}, 1983 \mathrm{~b}$ ) and in many other animal taxa (Baccetti \& Afzelius, 1976). Spermiogenesis in architectonicids (Healy, 1982b, 1984) follows the pattern seen in other euthyneurans, with the exception that neither paracrystalline layers nor a glycogen helix are formed during formation of the midpiece (in Heliacus, a helical paracrystalline structure lies within the mitochondrial sheath, but this is undoubtedly an independently acquired feature).

\section{Spermatozoa}

Spermatozoa of pyramidellids possess all the features expected of euthyneuran gastropod spermatozoa. These features include: (1) acrosome composed of an apical vesicle and acrosomal pedestal; (2) nucleus with helical keels (keels not always present or well developed); (3) complex, helically-keeled midpiece composed of an axoneme, coarse fibres (rarely absent), enveloping mitochondrial derivative (paracrystalline and matrix layers), one or more incorporated glycogen helices; (4) often a glycogen piece preceeded by a ring structure (at the glycogen piece/midpiece junction). In spermatozoa/ spermatids of all pyramidellid species which have been investigated ultrastructurally (Odostomia sp.: Thompson, 1973; Cingulina sp., Hinemoa sp., Turbonilla sp., Pyrgulina sp.: this paper; Otopleura spp.: Healy, 1984) only a single glycogen helix occurs within the midpiece, and this seems to be the case in most other euthyneuran species [though two to four helices occur in sperm of some basommatophorans such as lymnaeids and ellobiids (cf. Healy, 1983a), and some cephalaspidean opisthobranchs (Thompson, 1973; Healy, 1984)]. Similarly short, curved or helically-keeled sperm nuclei are encountered in most pyramidellids and most other euthyneuran species [long sperm nuclei deeply penetrated by the axoneme/coarse fibre complex occur in the pyramidelloidean Ebala nitidissima (Healy, unpublished data), Rissoella spp. (Healy, 1984), anaspid and some notaspid species (Thompson, 1973; Kubo \& Ishikawa, 1981; Healy \& Willan, 1984), and probably some cephalaspid species (see Franzén, 1955; Ghiselin, 1966)]. The acrosomal complex of pyramidellid spermatozoa is simple in comparison to acrosomes of some other opisthobranchs and a few pulmonates, where the pedestal component is either intert-

Fig. 5. Turbonilla sp. A Longitudinal section through nucleus-midpiece junction, showing detail of attached centriolar derivative, axoneme, coarse fibres (note periodic banding) $(\times 55400)$. B Transverse section through nucleus showing nuclear keels $(\times 42400)$. C Transverse section through basal invagination of nucleus. Coarse fibres, axoneme fuse with the centriolar derivative $(\times 43300)$. D Nucleus-midpiece junction of late spermatid - note subdivided structure of matrix component of the mitochondrial derivative $(\times 37800)$. E Transverse section through midpiece of almost mature spermatozoon. Note matrix and paracrystalline layers (x 46200$)$. F Longitudinal section (slightly oblique) through midpiece of late spermatid $(\times 33600)$. G Longitudinal section through midpieceglycogen piece junction and dense ring of mature spermatozoon ( $\times 33600)$. Inset: Transverse section of glycogen piece - note absence of intact axoneme $(\times 33600)$ 

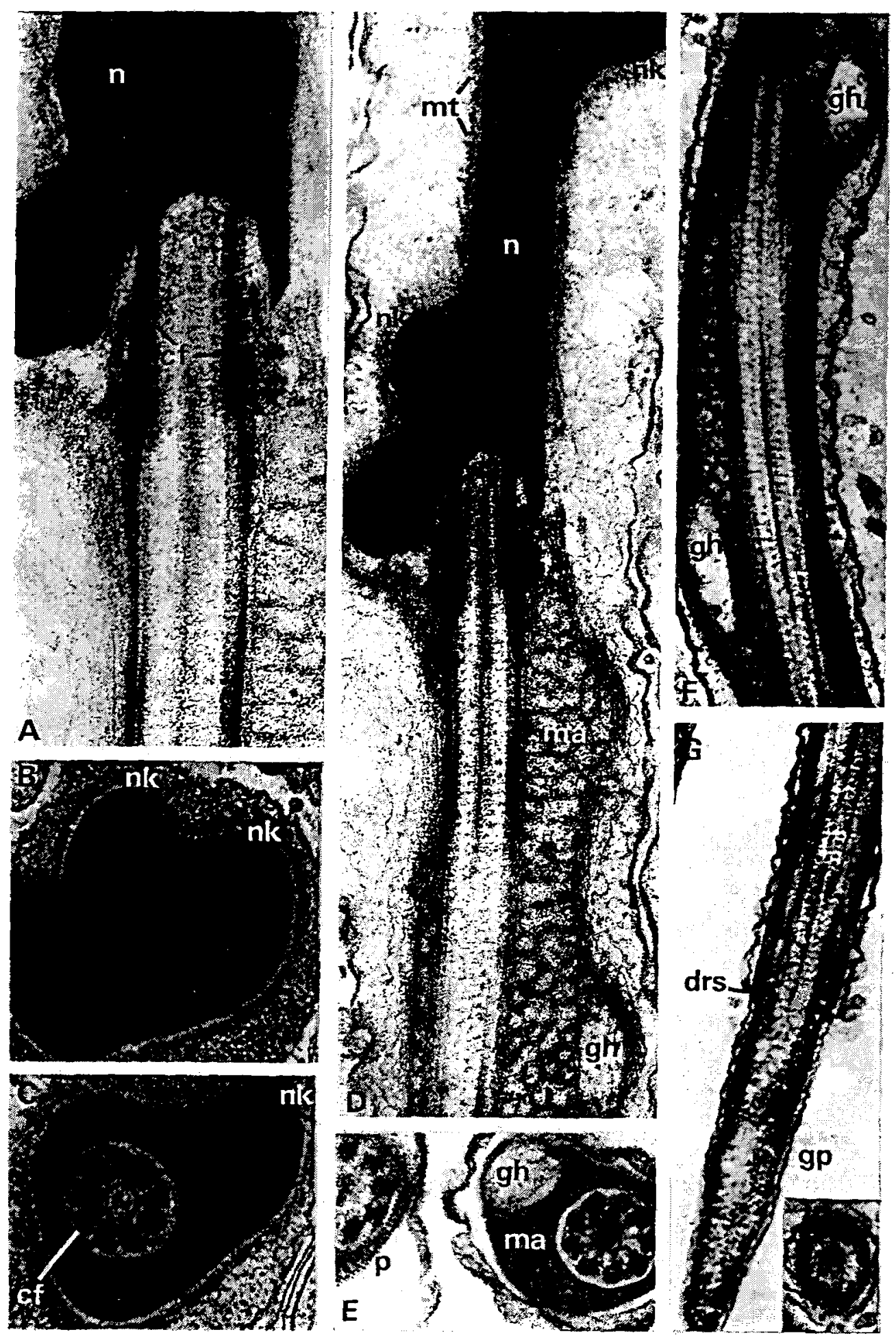
wined helically with the nucleus (Healy, 1982c, 1983a) or composed of more than one element (e.g. Onchidium: Healy, 1986). The glycogen piece is developed to varying degrees in sperm of pyramidellids (well developed in Cingulina, Pyrgulina, Odostomia: this paper; Thompson, 1973; poorly developed in Turbonilla: this paper). This is also the case in other euthyneuran species, though the precise reason for such variation is unknown. A glycogen piece has not been demonstrated in sperm of any stylommatophoran pulmonate but in euspermatozoa of mesogastropods (the presumed ancestors of the Euthyneura/Heterobranchia) and in neogastropod prosobranchs, it is always present and well-developed. Incorporation of glycogen within the midpiece in euthyneuran sperm may have made redundant the glycogen piece, hence its often reduced state (cf. Healy \& Willan, 1984).

\section{Systematic position of the Pyramidellidae}

Fretter \& Graham (1949) discussed the functional biology of various pyramidellid species belonging to the genera Odostomia, Turbonilla and Chrysallida. They noted important anatomical and shell similarities between pyramidellids and certain undisputed opisthobranchs, notably members of the Acteonidae and Ringiculidae, and concluded their paper by transferring the Pyramidellidae from the Prosobranchia to the Opisthobranchia. Prior to the work of Fretter and Graham, the Pyramidellidae were usually placed within the prosobranch order Mesogastropoda, often in combination with another parasitic family, the Eulimidae (this association = 'Aglossa' of Thiele, 1931 or Pyramidellacea sensu Wenz, 1938). Most workers now accept an opisthobranch position for the Pyramidellidae (and Pyramidelloidea), or at least the euthyneuran/heterobranch affiliation of this group (cf. Cox, 1960a,b; Knight et al., 1960; Taylor \& Sohl, 1962; Morton \& Yonge, 1964; Ghiselin, 1966; Hyman, 1967; Thompson, 1973; Climo, 1975; Fretter, 1980; Fretter \& Graham, 1962; Healy, 1982b, 1988; Haszprunar, 1985a-d; Fretter et al., 1986; Ponder \& Warén, 1988). Recently, however, the case in favour of prosobranch status for the Pyramidellidae has been revived by Golikov \& Starobogatov (1975), Gosliner (1981), and Robertson (1985). These authors also believe the Architectonicoidea, Rissoellidae and Omalogyridae to be true caeno/mesogastropods. While there may be some anatomical similarities between pyramidelloids/architectonicoids/rissoellids/ omalogyrids and certain mesogastropods such as the Epitonioidea (cf. Robertson, 1973, 1985), comparative ultrastructure of spermatozoa/spermiogenesis (Thompson, 1973;

Fig. 6. Hinemoa sp., Turbonilla sp., Cingulina sp., Pyrgulina sp. A (Hinemoa) Longitudinal section through acrosomal complex of late spermatid showing apical vesicle, acrosomal pedestal $(\times 43000)$. B (Turbonilla) Longitudinal section through acrosomal complex of late spermatid - support structures seen here and in Fig. $6 \mathrm{~A}$ will presumably be discarded at maturity $(\times 46200)$. C (Pyrgulina) Transverse section through midpiece and glycogen piece of mature sperm $(\times 55400)$. D-K (Cingulina). D-F Transverse sections through midpiece showing glycogen helix (note in Fig. 6D upper, that membranous material partly occupies the glycogen helix, but is displaced posteriorly by dense 'glycogen' granules (all $\times 55400$ ). G, H Transverse and oblique sections of midpiece below level of glycogen helix - note coarse fibres still associated with axonemal doublets, and also the subdivision of matrix material into helical tracts $(\times 62200)$. I Oblique transverse section of glycogen piece $(\times 62200)$. J, K Longitudinal sections through midpiece $(\mathrm{J}, \times 43600)$ and midpiece-glycogen piece junction - note dense ring structure $(\times 55400)$ 

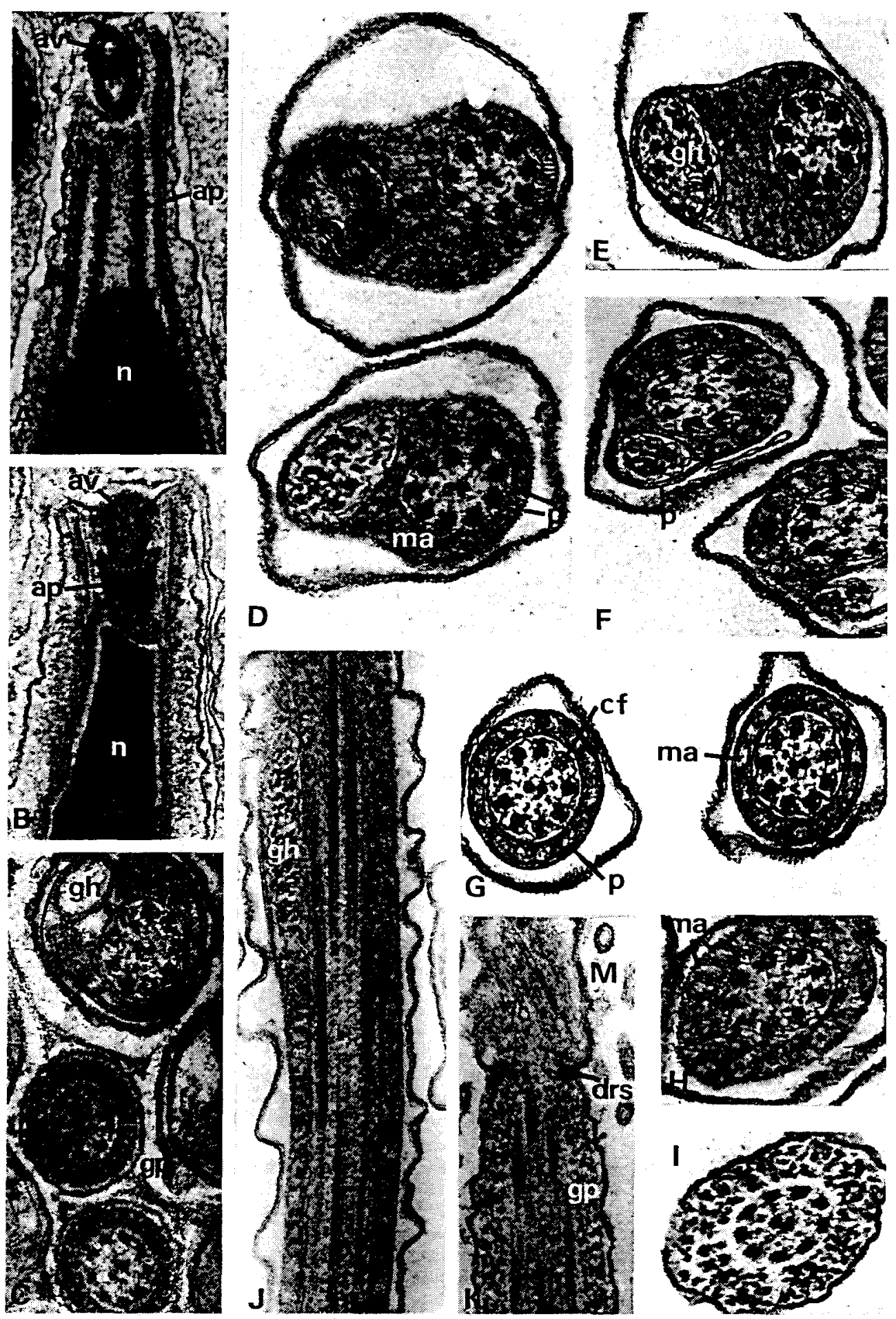
Healy, 1982b, 1984, 1988, this paper) indicate that all of these 'problem' groups are clearly allied to the Euthyneura/Heterobranchia and should be placed there (the view adopted by Ponder \& Warén, 1988). Haszprunar (1985a,b) places the Architectonicoidea and Pyramidelloidea within the Heterobranchia (Euthyneura) but treats the Rissoellidae and Omalogyridae as taxa transitional between mesogastropods and heterobranchs. The author agrees with the view that retention of higher prosobranch traits should be expected in the earliest euthyneuran gastropods (Ghiselin, 1966; Gosliner, 1981). Ghiselin envisages pyramidellids as arising from basal opisthobranchs, and interestingly, cites possession of complex, helically-keeled spermatozoa as a characteristic of any ancestral opisthobranch. Gosliner (1981) tries to accommodate the existence of complex 'euthyneuran' spermatozoa in pyramidellids by saying that the 'Pyramidellimorpha' (sensu Golikov \& Starobogatov, 1975 - essentially a revised 'Heterogastropoda' plus pyramidellids) and Euthyneura/Heterobranchia may have had a common ancestor. His diagrammatic phylogeny of the Gastropoda (Gosliner, 1981) however, precludes any relationship between the 'Pyramidellimorpha' and the Euthyneura, and more importantly there is no convincing evidence to link epitonioids and eulimoids with either the Pyramidelloidea or Architectonicoidea (for further discussion cf. Haszprunar, 1985a-d). The phylogenetic position of the Pyramidelloidea is uncertain. While fossil evidence hints that they are primitive and may have appeared as early as the Devonian-Carboniferous (assuming Streptacidae are pyramidelloideans - see Knight et al., 1960), their spermatozoa are fully 'euthyneuran' in character and not transitional between those of mesogastropods and euthyneurans.

To conclude, ultrastructural analysis of developing and mature sperm of pyramidellid gastropods confirms the view that they are euthyneuran/heterobranch gastropods assignable to the subclass Opisthobranchia, and not members of the prosobranch order Mesogastropoda.

Acknowledgements. The author thanks Dr. W. F. Ponder (Australian Museum, Sydney) for constructive comments on the manuscript and Dr. R. C. Willan (Department of Zoology, University of Queensland) for providing the specimen of Cingulina sp. used in this study. Technical assistance from the staff of the electron microscope units of the University of Sydney and University of Queensland is also gratefully acknowledged. Financial support for this project was provided by the Farrand Postdoctoral Research Fellowship of the University of Sydney, the Joyce W. Vickery Research Fund of the Linnean Society of New South Wales, and a Commonwealth Postgraduate: Award.

\section{LITERATURE CITED}

André, J., 1962. Contribution à la connaissance du chondriome. Étude de ses modifications ultrastructurales pendant spermiogenèse. - J. Ultrastruct. Res. (Suppl.) 3, 1-185.

Baccetti, B. \& Afzelius, B. A., 1976. Biology of the sperm cell. Karger, Basel, 254 pp.

Boss, K. J., 1982. Mollusca. In: Synopsis and classification of living organisms. Ed. by S. P. Parker. McGraw-Hill, New York, 2, 945-1166.

Buckland-Nicks, J. A. \& Chia, F. S., 1976. Spermatogenesis of a marine snail Littorina sitkana. - Cell Tiss. Res. $170,455-475$.

Climo, F. M., 1975. The anatomy of Gegania valkyrie Powell (Mollusca: Heterogastropoda: Mathildidae) with notes on other heterogastropods. - J R. Soc. N.Z. 5, 275-288.

Cox, L. R., 1960a. Gastropoda. General characteristics of Gastropoda. In: Treatise on invertebrate paleontology. Ed. by R. C. Moore. Univ. of Kansas Press, Lawrence, 84-169. 
Cox, L. R., 1960b. Thoughts on the classification of the Gastropoda. - Proc. malacol. Soc. Lond. 33 , $239-261$.

Dan, J. C. \& Takaichi, S., 1979. Spermiogenesis in the pulmonate snail Euhadra hickonis. III. Flagellum formation. - Dev. Growth Differ. 21, 71-86.

Eckelbarger, K. J. \& Eyster, L. S., 1981. An ultrastructural study on spermatogenesis in the nudibranch mollusk Spurilla neapolitana. - J. Morph. 170, 283-300.

Franzén, A., 1955. Comparative morphological investigations into the spermiogenesis among Mollusca. - Zool. Bidr. Uppsala. 30, 399-456.

Fretter, V., 1980. The evolution of some higher taxa in gastropods. - J. malacol. Soc. Aust. 4, 226-227.

Fretter, V. \& Graham, A., 1949. The structure and mode of life of the Pyramidellidae, parasitic opisthobranchs. - J. mar. biol. Ass. U.K. 48, 493-532.

Fretter, V. \& Graham, A., 1962. British prosobranch molluscs. Ray Society, London, 755 pp.

Fretter, V., Graham, A. \& Andrews, E. B., 1986. The prosobranch molluscs of Britain and Denmark. Part 9. Pyramidellacea. - J. moll. Stud. (Suppl.) 16, 557-649.

Ghiselin, M. T., 1966. Reproductive function and the phylogeny of opisthobranch gastropods. Malacologia, 3, 327-378.

Golikov, A. N. \& Starobogatov, Y. I., 1975. Systematics of prosobranch gastropods. - Malacologia, 15, 185-232.

Gosliner, T. M., 1981. Origins and relationships of primitive members of the Opisthobranchia (Mollusca: Gastropoda). - Biol. J. Linn. Soc. 16, 197-225.

Haszprunar, G., 1985a. The fine morphology of the osphradial sense organs of the Mollusca. II. Allogastropoda (Architectonicidae, Pyramidellidae). - Phil. Trans. R. Soc, (B). 307, 497-505.

Haszprunar, G., 1985b. The Heterobranchia - a new concept of the phylogeny of the higher Gastropoda. - Z. zool. Syst. Evolutionsforsch. 23, 15-37.

Haszprunar, G., 1985c. Zur Anatomie und systematischen Stellung der Architectonicidae (Mollusca, Allogastropoda). - Zool. Scr. 14, 25-43.

Haszprunar, G., 1985d. On the anatomy and systematic position of the Mathildidae (Mollusca, Allogastropoda). - Zool. Scr. 14, 201-213.

Healy, J. M., 1982a. An ultrastructural examination of developing and mature euspermatozoa in Pyrazus ebeninus (Mollusca, Gastropoda, Potamididae). - Zoomorphology 100, 157-175.

Healy, J. M., 1982b. Ultrastructure of spermiogenesis of Philippia (Psilaxis) oxytropis with special reference to the taxonomic position of the Architectonicidae (Gastropoda). - Zoomorphology 101, $197-214$.

Healy, J. M., 1982c. Ultrastructure of the spermatozoon of an opisthobranch, Tornatina sp. (Mollusca, Gastropoda, Retusidae). - Zool. Scr. 11, 221-226.

Healy, J. M., 1983a. An ultrastructural study of basommatophoran spermatozoa (Mollusca, Gastropoda). - Zool. Scr. 12,57-66.

Healy, J. M., 1983b. Ultrastructure of euspermiogenesis in the mesogastropod Stenothyra sp. (Prosobranchia, Rissoacea, Stenothyridae). - Zool. Scr. 12, 203-214.

Healy, J. M., 1984. The ultrastructure of gastropod spermatozoa and spermiogenesis. Ph. D. Thesis, Univ. of Queensland, Brisbane, $370 \mathrm{pp}$.

Healy, J. M., 1986. Electron microscopic observations on the spermatozoa of a marine pulmonate slug Onchidium damelli (Gastropoda, Onchidiacea). - J. submicrosc. Cytol. 18, 587-594.

Healy, J. M., 1988. Sperm morphology and its systematic importance in the Gastropoda. - Malacol. Rev. (Suppl.) 4 (In press.)

Healy, J. M. \& Willan, R. C., 1984. Ultrastructure and phylogenetic significance of notaspidean spermatozoa (Mollusca, Gastropoda, Opisthobranchia). - Zool. Scr. 13, 107-120.

Hyman, L., 1967. The invertebrates. McGraw-Hill, New York, 6, 1-792.

Knight, J. B., Batten, R. L., Yochelson, E. \& Cox, L. R., 1960. Paleozoic and some Mesozoic Caenogastropoda and Opisthobranchia (supplement). In: Treatise on invertebrate paleontology. Ed. by R. C. Moore. Univ. of Kansas Press, Lawrence, 310-324.

Kubo, M. \& Ishikawa, M., 1981. Organization of the acrosome and helical structures in sperm of the aplysiid Aplysia kurodai (Gastropoda, Opisthobranchia). - Differentiation 20, 131-140.

Medina, A., Moreno, J. \& Lopez-Camps, J. L., 1985. Acrosome evolution in Hypselodoris tricolor (Gastropoda: Nudibranchia). - J. submicrosc. Cytol. 17, 403-411. 
Medina, A., Moreno,.J. \& Lopez-Camps, J. L., 1986. Nuclear morphogenesis during spermiogenesis in the nudibranch mollusc Hypselodoris tricolor (Gastropoda, Opisthobranchia). - Gamete Res. $13,159-171$.

Morton, J. E. \& Yonge, C. M., 1964. Classification and structure of the Mollusca. In: Physiology of mollusca. Ed. by K. M. Wilbur \& C. M. Yonge. Acad. Press, New York. 1-58.

Ponder, W. F., 1973. Pseudoskenella depressa gen. et sp. nov., an ectoparasite on Galeolaria. Malacol. Rev, 6, 119-123.

Ponder, W. F. \& Warén, A., 1988. Classification of the Caenogastropoda and Heterostropha - a list of the family-group and higher category names. - Malacol. Rev. (Suppl. ) 4 (In press.)

Robertson, R., 1973. The biology of the Architectonicidae: gastropods combining prosobranch and opisthobranch traits. - Malacologia. 14, 215-220.

Robertson, R., 1978. Spermatophores of six eastern North American pyramidellid gastropods and their systematic significance (with the new genus Boonea). - Biol. Bull. mar. biol. Lab., Woods Hole $155,360-382$.

Robertson, R., 1985. Four characters and the higher category systematics of gastropods. - Am. malcol. Bull. 1, 1-22.

Takaichi, S. \& Dan, J. C., 1977. Spermiogenesis in the pulmonate snail Euhadra hickonis. I. Acrosome formation. - Dev. Growth Differ. 19, 1-14.

Takaichi, S. \& Sawada, N., 1973. An electron microscope study on sperm formation in Euhadra hickonis. - Mem. Ehime Univ, (B) 7, 17-58.

Taylor, D. W. \& Sohl, N., 1962. An outline of gastropod classification. - Malacologia 1, 7-32.

Terakado, $K, 1981$. Chromatin arrangement and axis formation in the spermiogenesis of a pulmonate snail. - Dev. Growth Differ. 23, 381-399.

Thiele, J., 1931. Handbuch der systematischen Weichtierkunde. Fischer, Jena, 1, 1--376.

Thompson, T. E., 1973. Euthyneuran and other molluscan spermatozoa. - Malacologia 14, 167-206; $243-244$.

Wenz, W., 1938. Gastropoda 1. Allgemeiner Teil und Prosobranchia. In: Handbuch der Paläozoologie. Ed. by O. H. Schindewolf. Borntraeger, Berlin, $6,1-240$. 